\title{
INFECTION BY CYTOMEGALOVIRUS IN PATIENTS WITH NEONATAL CHOLESTASIS
}

\author{
Nara Léia Gelle de OLIVEIRA ${ }^{3}$, Fernanda Rafful KANAWATY ${ }^{3}$, \\ Sandra Cecilia Botelho COSTA ${ }^{2}$ and Gabriel HESSEL ${ }^{1}$
}

ABSTRACT - Background - Neonatal cholestasis syndrome with an intra or extrahepatic origin has been associated to viral infections. The participation of the cytomegalovirus in the etiopathogenesis of neonatal hepatitis has been already known for some time, but only recently there have been indications that this virus may be one of the possible etiological factors for extrahepatic biliary atresia. Aims - To assess the prevalence of infection by cytomegalovirus in patients with intrahepatic cholestasis and extrahepatic cholestasis. To compare the clinical characteristics of the intrahepatic cholestasis and extrahepatic cholestasis groups with the cytomegalovirus serological results. Patients and Methods - This study consisted of 76 patients with neonatal cholestasis who were admitted between January 1980 and January 1999 when they underwent a cytomegalovirus serologic study using the ELISA method. A case note was kept on each patient with the following data: age of patient at admission, serologic result for cytomegalovirus, history of maternal infection, prematurity, fetal distress, birth weight, ponderal gain, choluria and fecal acholia. The final anatomic diagnosis of cholestasis was based on the results of an abdominal ultrasonography, a liver biopsy and its evolution. The patients were then divided into two groups: group I - intrahepatic cholestasis and group II - extrahepatic cholestasis. Each of these groups were then divided into two subgroups: subgroup A positive serology (IgM) for cytomegalovirus and subgroup B - negative serology (IgM) for cytomegalovirus. Results - The frequency of positive serology (IgM) for cytomegalovirus was $29.4 \%$ in children with intrahepatic cholestasis and $28.5 \%$ in children with extrahepatic cholestasis. In comparison with group IIB, group IIA presented a higher rate of maternal infection history. The patients in group IIA demonstrated a delayed access to the service in comparison with group IA. The groups did not demonstrate any significant differences regarding the onset age of jaundice, choluria and fecal acholia, birth weight and ponderal gain. Conclusions - The positive (IgM) seroprevalence for cytomegalovirus in children with intrahepatic cholestasis and extrahepatic cholestasis is high. The history of maternal infection was more common in extrahepatic cholestasis patients with positive serology for cytomegalovirus. There was a delay in the referral of these patients which resulted in a late diagnosis and surgical treatment.

HEADINGS - Cytomegalovirus infections. Bile duct obstruction, extrahepatic. Cholestasis, intrahepatic.

\section{INTRODUCTION}

The occurrence of neonatal cholestasis has been associated to congenital or acquired viral infections. Previous studies based on serologic tests indicated that the herpes group virus, especially cytomegalovirus (CMV) was implicated in the development of intrahepatic neonatal cholestasis ${ }^{(16)}$.

Infections due to CMV are present in about $1 \%$ to $2.4 \%$ of newborns in North America and in our country ${ }^{(5,22,26)}$, but at the end of the first year of life, this very same infection is present in up to $60 \%$ of the children in the west ${ }^{(11,12)}$.
Intrauterine CMV transmission is due to primary or recurring maternal infections and it causes the greatest damages to the fetus when it occurs in the early pregnancy stages $^{(6)}$. However, the risk of fetal transmission seems greater when the maternal infection occurs during the final pregnancy trimester ${ }^{(15,18,20)}$. The fetal infection may cause: the interruption of the pregnancy, prematurity, low birth weight in full term newborns and several congenital malformations such as inguinal hernia, cleft palate, dental abnormalities, polycystic kidneys, mitral and pulmonary stenosis, atrial and ventricular septal defects and atresia of the biliary ducts ${ }^{(7,21)}$.

Study conducted by the Departaments of ${ }^{1}$ Pediatrics and ${ }^{2}$ Medical Clinic of the ${ }^{3}$ Faculty of Medical Sciences (FCM), State University of Campinas - UNICAMP, Campinas, SP, Brazil.

Address for correspondence: Dr. Gabriel Hessel - Departamento de Pediatria - FCM/UNICAMP - Caixa Postal 6111 - 13083-970 - Campinas, SP, Brazil. e-mail: pediat@head.fcm.unicamp.br 
The clinical symptoms of cytomegalovirus in full term neonates varies from an asymptomatic condition to a fully disseminated terminal condition. When the disease is clearly manifested in neonates they frequently show: jaundice, hemorrhagic suffusion, hepatosplenomegaly, microcephaly, chorioretinitis, deafness, and neuromuscular dysfunctions. The main laboratory findings are: anemia, thrombocytopenia, and periventricular calcification of the central nervous system ${ }^{(14)}$.

On the other hand, a perinatal infection occurs more frequently than a congenital infection, and the main source of infection is the maternal contact, either through cervical secretion during delivery or later through breast feeding, as the virus was found in both secretions obtained from seropositive CMV asymptomatic pregnant women $^{(9,10,18)}$. A CMV perinatal infection usually presents an asymptomatic clinical development which appears as a cholestatic syndrome ${ }^{(2,23)}$.

Neonatal cholestatic syndrome may be a result of an intrahepatic or extrahepatic alterations. The etiologies of the intrahepatic group are included in one of the following subgroups: metabolic, toxicmedication, hereditary, anatomic and idiopathic infections. The main etiologies of the extrahepatic group are atresia of the extrahepatic biliary atresia (EHBA) and choledochal cysts.

EHBA is the final result of a destructive inflammatory process that affects the intrahepatic and extrahepatic biliary ducts leading to fibrosis and obliteration of the biliary tract at some point between the porta hepatis and the duodenum. The etiology of the disease is unknown, although there is a definite attractiveness in a hypothesis incriminating an in utero viral insult to the hepatobiliary system. The viruses studied in children with EHBA were reovirus type 3, rotavirus and CMV, but the results in relation to viral participation were controversial and inconclusive $\mathrm{e}^{(1)}$

Therefore, this study had the following aims: 1) to evaluate the prevalence of infection due to CMV in patients with intrahepatic cholestasis (IHC) and extrahepatic cholestasis (EHC); 2) to compare the clinical characteristics of the IHC and EHC groups with positive and negative serology for CMV.

\section{CASUISTIC AND METHODS}

A retrospective study was conducted in 147 patients who were admitted with neonatal cholestasis to the Pediatric Gastroenterology Unit, University Hospital, Faculty of Medical Sciences, State University of Campinas (HC-UNICAMP), Campinas, SP, Brazil, between January 1980 and January 1999. A case note was kept on each of these patients with the following data: age of patient at admission; serologic result for $\mathrm{CMV}, \mathrm{IgG}$, and $\operatorname{IgM}$; history of maternal infection; prematurity; fetal distress; birth weight; ponderal gain; jaundice; choluria and fecal acholia.
The age at onset was also noted for the last three items whenever they were present. After reporting all these items, 71 patients were excluded because they did not present serology for CVM ( $\mathrm{n}$ $=28$ ) or the serological study did not differentiate between $\operatorname{IgG}$ and $\operatorname{IgM}(\mathrm{n}=40)$ or even the results for $\operatorname{IgM}$ were doubtful during the first examination $(n=3)$. At end there were 76 patients included in the study and they underwent serology for CVM using the ELISA method.

The final anatomic diagnosis of cholestasis was based on the results of an abdominal ultrasonography, a liver biopsy and the evolution. The patients were then divided into two groups: group I IHC and group II - EHC. Each of these groups were then divided into two subgroups: subgroup A - positive serology ( $\operatorname{IgM})$ for CMV and subgroup B - negative serology (IgM) for CMV.

\section{Statistical analysis}

Double entry tables were used to calculate the prevalence as well as to compare the categorical variables of the groups. The relationship between the variables was found out using the Chi-square test and the Exact Fisher test whenever necessary. The non-parametric Kruskal-Wallis test was used to compare the continuing variables. The level of significance adopted was $P=0.05^{(19)}$.

\section{RESULTS}

Table 1 presents the number of IHC and EHC patients with a positive serology for CMV.

In the IHC group there were $29.4 \%$ with positive serology for CMV and in the EHC group, $28.5 \%$ with positive serology for CMV. This meant that there was no statistical significant difference.

Table 2 presents crossing of data: categorical variables, type of cholestasis and serological result for CMV.

The only variable that presented a statistical difference was the history of maternal infections.

Table 3 presents crossing of data: continuing variables, type of cholestasis and results of serology for CMV.

The only variable that demonstrated a significant statistical difference was the age (days) at the first consultation.

\section{DISCUSSION}

The results of this study indicated a high prevalence of CMV in children with both intrahepatic and extrahepatic neonatal cholestasis. It has been already known for sometime that this virus is a participant in the etiopathogenesis of neonatal hepatitis ${ }^{(16,17)}$, but only recently it has been indicated as a possible etiologic factor in $\mathrm{EHBA}^{(4,24)}$. 
TABLE 1 - Results of serology (IgM positive) for cytomegalovirus in group I (IHC) and in group II (EHC)

\begin{tabular}{cccc}
\hline Group & CMV negative & CMV positive & Total \\
\hline I & 24 & 10 & 34 \\
II & 30 & 12 & 42 \\
Total & 54 & 22 & 76 \\
\hline
\end{tabular}

TABLE 2 - Results in percentage of some of the categorical variables studied in children with neonatal cholestasis. Group IA = IHC and positive serology for CMV; group IB = IHC and negative serology for CMV; group $\mathrm{IIA}=\mathrm{EHC}$ and positive serology for CMV and group IIB = EHC and negative serology for CMV. The value of $P$ is for the following comparisons: IA x IIA; IB x IIB; IA x IB and IIA x IIB

\begin{tabular}{lccccc}
\hline Items studied & Group IA & Group IB & Group IIA & Group IIB & Value of $\boldsymbol{P}$ \\
\hline Choluria & 80,00 & 86,96 & 83,33 & 92,86 & $>0,05$ \\
Fecal Acholia & 70,00 & 82,61 & 100,00 & 90,00 & $>0,05$ \\
History of & 22,22 & 22,22 & 41,67 & 8,70 & IIA x IIB \\
maternal & & & & $<0,05$ \\
infections & & & & Others \\
& & & & 78,57 & $>0,05$ \\
Full term birth & 50,00 & 59,09 & 91,67 & 8,33 & $>0,05$ \\
Fetal distress & 33,33 & 14,29 & 0,00 & & \\
\hline
\end{tabular}

TABLE 3 - The results of the mean and median (showed between parenthesis) of some of the continuing variables studied in children with neonatal cholestasis. Group IA = IHC and positive serology for CMV; group IB = IHC and negative serology for CMV; group IIA = EHC and positive serology for CMV and group IIB $=\mathrm{EHC}$ and negative serology for CMV. The value of $P$ is for the following comparisons: IA $\mathrm{x}$ IIA; IB $\mathrm{x}$ IIB; IA $x$ IB e IIA x IIB

\begin{tabular}{|c|c|c|c|c|c|}
\hline Items studied & Group IA & Group IB & Group IIA & Group IIB & Value of $P$ \\
\hline \multirow[t]{2}{*}{$\begin{array}{l}\text { Age (days) at the } 1^{\text {st }} \\
\text { consultation }\end{array}$} & $\begin{array}{c}63,60 \\
(58,00)\end{array}$ & $\begin{array}{c}66,56 \\
(54,00)\end{array}$ & $\begin{array}{c}109,16 \\
(109,00)\end{array}$ & $\begin{array}{c}91,16 \\
(77,00)\end{array}$ & $\begin{array}{c}\text { IA } x \text { IIA< } \\
0,05\end{array}$ \\
\hline & & & & & Others $>0,05$ \\
\hline $\begin{array}{l}\text { Age at onset of } \\
\text { jaundice (days) }\end{array}$ & $\begin{array}{l}19,20 \\
(7,00)\end{array}$ & $\begin{array}{l}20,43 \\
(7,00)\end{array}$ & $\begin{array}{c}3,16 \\
(1,00)\end{array}$ & $\begin{array}{l}12,07 \\
(3,00)\end{array}$ & $>0,05$ \\
\hline $\begin{array}{l}\text { Age at onset of } \\
\text { choluria (days) }\end{array}$ & $\begin{array}{c}35,25 \\
(31,00)\end{array}$ & $\begin{array}{l}16,09 \\
(2,00)\end{array}$ & $\begin{array}{c}36,00 \\
(15,00)\end{array}$ & $\begin{array}{l}11,04 \\
(5,00)\end{array}$ & $>0,05$ \\
\hline $\begin{array}{l}\text { Age at onset of } \\
\text { acholia (days) }\end{array}$ & $\begin{array}{c}36,57 \\
(36,00)\end{array}$ & $\begin{array}{c}29,00 \\
(30,00)\end{array}$ & $\begin{array}{c}37,20 \\
(26,00)\end{array}$ & $\begin{array}{l}14,86 \\
(6,50)\end{array}$ & $>0,05$ \\
\hline $\begin{array}{l}\text { Birth weight } \\
(\mathrm{gm})\end{array}$ & $\begin{array}{c}2884,00 \\
(3160,00)\end{array}$ & $\begin{array}{c}2938,00 \\
(2932,50)\end{array}$ & $\begin{array}{c}3228,00 \\
(3140,00)\end{array}$ & $\begin{array}{c}3171,50 \\
(3065,00)\end{array}$ & $>0,05$ \\
\hline $\begin{array}{l}\text { Ponderal gain } \\
\text { (gm/day) }\end{array}$ & $\begin{array}{c}20,17 \\
(22,37)\end{array}$ & $\begin{array}{c}19,69 \\
(20,96)\end{array}$ & $\begin{array}{c}17,95 \\
(19,10)\end{array}$ & $\begin{array}{c}14,52 \\
(12,69)\end{array}$ & $>0,05$ \\
\hline
\end{tabular}


CHANG et al. ${ }^{(3)}$, used the polymerase chain reaction (PCR) to study CMV in liver tissue of children with neonatal cholestasis and it was found that out of 50 children with IHC, 23 children were positive and in 26 children with EHBA, only 2 were positive. JEVON and DIMMICK $^{(8)}$, had similar results. They did not find any patient with CMV among the 12 children with EHBA who were studied using PCR in the liver tissue.

FISCHLER et al. ${ }^{(4)}$, on the other hand, studied 59 children with neonatal cholestasis and found that $32 \%$ presented IgM-CMV, while $6 \%$ of the children in the control group (without cholestasis) were positive. This positive percentage included, both, children with IHC (11 out of 38 ) as well as children with EHBA (8 out of 21). When these authors used the PCR to study this virus in the liver tissue, the number of children found to be positive was much higher: $50 \%$ prevalence ( 9 out of 18 ) in children with EHBA; $42.8 \%$ (3 out of 7 ) in children with other types of cholestasis. These diverging results may be due to the difference in the prevalence of this virus in the general population or a difference in the CMV infecting strain.

The detection of a specific IgM-CMV after the $4^{\text {th }}$ week of life may be a consequence of a congenital or perinatal infection. Previous studies made in Brazil had shown that a positive prevalence of $\operatorname{IgM}$ to CMV between the $2^{\text {nd }}$ and the $4^{\text {th }}$ month of life varies from $8.1 \%$ to $14.7 \%$. Therefore, when it is putting along with the detection method of CMV at the urine by viral isolation in cultured cells, this prevalence of the infection increases about from $30.9 \%$ to $38 \%$, being asymptomatic in the great majority of cases ${ }^{(13,25)}$. Based on these results, it would be interesting the inclusion of a control group of children without neonatal cholestasis, with an equivalent age group, although it was not possible due to the fact that is a retrospective study. So, the presence of a specific IgM to CMV only suggests that this virus may be the etiologic agent of the neonatal cholestasis syndrome but it does not confirm it.

An analysis of some of the categorical variables showed that regarding the history of maternal infection variable, there was a significant difference between the subgroups IIA and IIB. In these subgroups, the serology was also negative for other infectious agents routinely studied: syphilis, toxoplasmosis, rubella and hepatitis B. It is likely that a significant percentage of mothers with IgM-CMV children with EHBA presented a reactivation of the disease during pregnancy. This hypothesis is based on the study conducted by FISCHLER et al. ${ }^{(4)}$, who observed a greater proportion of seropositive mothers (IgG for CVM) in the group of children with neonatal cholestasis than in the control group, and in the same way, a greater percentage of these mothers demonstrated an increased IgG for CMV.

After analyzing some continuing variables, no difference was observed between the subgroups regarding onset age for jaundice, choluria, and fecal acholia. Similarly, no difference was observed between the subgroups regarding birth weight and ponderal gain. On the other hand, a difference was observed between the subgroups IA and IIA regarding the age at the first consultation at the Pediatric Gastroenterology Unit, HC-UNICAMP, which meant a delayed referral for the subgroup with EHBA and positive serology for CVM. The following report found at the case notes of the subgroup IIA patients is common: mother brought the child to the doctor complaining of jaundice and several investigations were requested by the physician. The results confirmed that the hepatitis was viral and therefore it was needed a period of resting. The jaundice worsened and the child was referred to the Pediatric Gastroenterological Unit, HC-UNICAMP where the final anatomic diagnosis was EHBA. The treatment recommended for this disease is surgical and should be performed as early as possible and the ideal timing is before the age of 2 months. As seen in this study, the mean and median age at which the child was brought to this service was approximately $3^{1 / 2}$ months and in most cases the delay for referral was definitely because the results showed a positive serology (IgM) for cytomegalovirus. Hence, in many cases the patient missed the opportunity of undergoing a surgery to restore the biliary flow or when the surgery was performed, the results were usually unsatisfactory.

In conclusion, in children with IHC and EHC, the positive (IgM) seroprevalence for CVM was high. The virus in the liver tissue is being investigated using PCR in our laboratory to find out the actual prevalence and etiopathogenic participation of this virus in neonatal cholestasis. The presence of positive IgM serology for CVM must not interrupt the procedures used to differentiate IHC from EHC. 
Oliveira NLG, Kanawaty FR, Costa SCB, Hessel G. Infecção por cytomegalovirus em pacientes com colestase neonatal. Arq Gastroenterol 2002;39(2):132-136.

RESUMO - Racional - A síndrome colestática neonatal, de origem intra ou extra-hepática, tem sido associada à presença de infecções virais. A participação do cytomegalovirus na etiopatogênese da hepatite neonatal já é conhecida há algum tempo e só recentemente esse vírus tem sido implicado como dos possíveis fatores etiológicos da atresia de vias biliares extra-hepática. Objetivos - Calcular a prevalência da infecção pelo cytomegalovirus em pacientes com colestase intra-hepática e colestase extra-hepática e comparar algumas características clínicas entre os grupos de colestase intra-hepática e colestase extra-hepática com o resultado de sorologia para cytomegalovirus. Casuística e Métodos Participaram do estudo 76 pacientes com colestase neonatal admitidos durante o período de janeiro de 1980 a janeiro de 1999 que realizaram pesquisa sorológica para cytomegalovirus pelo método ELISA. Para todos esses pacientes foi elaborada uma ficha contendo os seguintes dados: idade do paciente na admissão, resultado de sorologia para cytomegalovirus, história de infecção materna, prematuridade, sofrimento fetal, peso de nascimento, ganho ponderal, colúria e acolia fecal. O diagnóstico anatômico final da colestase fundamentou-se no resultado de ultrasonografia abdominal, biopsia hepática e evolução. Dessa forma, os pacientes foram divididos em dois grupos: I - colestase intra-hepática e II - colestase extra-hepática. Cada um desses grupos foi dividido em dois subgrupos: A - com sorologia positiva (IgM) para cytomegalovirus e B com sorologia negativa (IgM) para cytomegalovirus. Resultados - A freqüência observada de sorologia positiva (IgM) para cytomegalovirus nas crianças com colestase intra-hepática e colestase extra-hepática foi de $29,4 \%$ e $28,5 \%$, respectivamente. O grupo IIA apresentou percentual maior de história de infecção materna quando comparado ao grupo IIB. Os pacientes do grupo IIA apresentaram acesso mais tardio ao Serviço em relação àqueles do grupo IA. Não foram observadas diferenças significativas entre os grupos em relação à idade de início da icterícia, colúria e acolia fecal, bem como em relação ao peso de nascimento e ganho ponderal. Conclusões - A prevalência de sorologia positiva (IgM) para cytomegalovirus em crianças com colestase intra-hepática e colestase extra-hepática é alta. A história de infecção materna é mais comum nos pacientes com colestase extra-hepática e sorologia positiva para cytomegalovirus. Nesses pacientes, o encaminhamento foi mais tardio com atraso no diagnóstico e no tratamento cirúrgico.

DESCRITORES - Infecções por cytomegalovirus. Obstrução das vias biliares extra-hepáticas. Colestasia intra-hepática.

\section{REFERENCES}

1. Balistreri WF, Grand R, Hoofnagle JH, Suchy FJ, Ryckman FC, Perlmutter DH, Sokol RJ. Biliary atresia: current concepts and research directions. Hepatology 1996;23:1682-92

2. Boppana SB, Pass RF, Britt WJ, Stagno S, Alford CA. Symptomatic congenital cytomegalovirus infection: neonatal morbidity and mortality. Pediatr Infect Dis J 1992;11:93-9.

3. Chang MH, Huang HH, Huang ES, Kao CL, Hsu HY, Lee CY. Polymerase chain reaction to detect human cytomegalovirus in livers of infants with neonatal hepatitis. Gastroenterology 1992;103:1022-5.

4. Fischler B, Ehrnst A, Forsgren M, Örvell C, Nemeth A. The viral association of neonatal cholestasis in Sweden: a possible link between cytomegalovirus infection and extrahepatic biliary atresia. J Pediatr Gastroenterol Nutr 1998;27:57-64.

5. Fowler KB, Stagno S, Pass RF. Maternal age and congenital cytomegalovirus infection: screening of two diverse newborn populations, 1980-1990. J Infect Dis 1993;168:552-6.

6. Griffiths PD, Baboonian C. A prospective study of primary cytomegalovirus infection during pregnancy: final report. Br J Obstet Gynaecol 1984;91:30715.

7. Hanshaw JB. Congenital cytomegalovirus infection: a fifteen year perspective. J Infect Dis 1971;123: 555-61.

8. Jevon GP, Dimmick JE. Biliary atresia and cytomegalovirus infection: a DNA study. Pediatr Dev Pathol 1999;2:11-4.

9. Kumar ML, Nankervis GA, Cooper AR, Gold E. Postnatally acquired cytomegalovirus infections in infants of CMV excreting mothers. J Pediatr 1984;104:669-73

10. Leinikki P, Granstrüm ML, Santavuori P, Pettay O. Epidemiology of cytomegalovirus infections during pregnancy and infancy: a prospective study. Scand J Infect Dis 1978;10:165-71.

11. Leinikki P, Heinonen K, Pettay O. Incidence of cytomegalovirus infections in early childhood. Scand J Infect Dis 1972;4:1-5.

12. Levinsohn EM, Foy HM, Kenny GE, Wentworth BB, Grayston JT. Isolation of cytomegalovirus from a cohort of 100 infant throughout the first year of life. Proc Soc Exp Biol Med 1969;132:957-62.

13. Machado CM, Fink MCDS, Vilas Boas LS, Sumita LM, Weinberg A, Shiguematsu K, Souza IC, Casa Nova LD, Pannuti CS. Infecção perinatal pelo citomegalovírus em hospital público do município de São Paulo: estudo prospectivo. Rev Inst Med Trop São Paulo 1991;33:159-66.

14. Mediaris DN. Observations concerning human cytomegalovirus infection and disease. Bull Johns Hopkins 1964;114:181-211.

15. Nankervis GA, Kumar ML, Cox FE, Gold E. A prospective study of materna cytomegalovirus infection and its effect on the fetus. Am J Obstet Gynecol 1984;149:435-40.

16. Poley JR. Syndromes of neonatal cholestasis. In: Gracey M, Burke V, editors Pediatric gastroenterology and hepatology. 3. ed. Boston: Blackwell Scientific; 1993. p.566-93.

17. Prado ETML, Araujo MF, Campos JVM. Colestase neonatal prolongada: estudo prospectivo. Arq Gastroenterol 1999;36:185-94.

18. Reynolds DW, Stagno S, Hosty TS, Tiller M, Alford CA. Maternal cytomegalovirus excretion and perinatal infection. N Engl J Med 1973;289:1-5.

19. Siegel S. A prova de Kruskal-Wallis e o caso de duas amostras independentes. In: Siegel S, editor. Estatística não-paramétrica. São Paulo: McGraw-Hill; 1975. p.107-24; p.209-19.

20. Stagno S, Pass RF, Dworsky ME, Henderson RE, Moore EG, Walton PD, Alford CA. Congenital cytomegalovirus infection: the relative importance of primary and recurrent maternal infection. N Engl J Med 1982;306:945-9.

21. Stagno S, Pass RF, Thomas JP, Navia JM, Dworsky ME. Defects of tooth structure in congenital cytomegalovirus infection. Pediatrics 1982;69:646-8.

22. Stagno S, Reynolds DW, Huang ES, Thames SD, Smith RJ, Alford CA. Congenital cytomegalovirus infection: occurrence in immune population. N Engl J Med 1977;296:1254-8

23. Starr JG, Bart RD, Gold E. Inapparent congenital cytomegalovirus infection: clinical and epidemiologic characteristics in early infancy. N Engl J Med 1970;282:1075-8

24. Tarr PI, Haas JE, Christie DL. Biliary atresia, cytomegalovirus and age at referral. Pediatrics 1996;97:828-31.

25. Yamamoto AY, Figueiredo LTM, Mussi-Pinhata MM. Infecção perinatal por citomegalovírus: muito freqüente mas pouco diagnosticada. J Pediatr (Rio de Janeiro) 1999;75:126-30.

26. Yamamoto AY, Mussi-Pinhata MM, Pinto PC, Figueiredo LT, Jorge SM Congenital cytomegalovirus infection in preterm and full-term newborn infants from a population with a high seroprevalence rate. Pediatr Infect Dis J 2001;20:188-92.

Recebido em 13/12/2001. Aprovado em 17/5/2002. 